\title{
Impact of International Trade on Economic Growth: The Nigerian Experience
}

\author{
Chukwuemeka Nwamuo, Ph.D \\ Department of Economics, Obong University, ObongNtak, AkwaIbom state - Nigeria
}

\begin{abstract}
The study investigated the impact of international trade on economic growth in Nigeria: Annual time series data were obtained from the Central Bank of Nigeria Statistical Bulletin for the period 1981 to 2018 on the variables used for the study. Unit root test was conducted using Augmented Dickey-Fuller test technique and the result showed that the variables were stationary though at different levels. Co-integration test was also conducted using Johanssen co-integration test method and the result showed that the variables in the model were co-integrated meaning that the variables have a long run relationship. The regression result showed that export, import and exchange rate have a positive impact on the economic growth of Nigeria while trade openness has a negative impact on the economic growth of Nigeria The R-squared value showed that about $99 \%$ of the total variations in the dependent variable were explained by changes in the explanatory variables The error correction result showed that the speed of adjustment to long run equilibrium is 65.9 percent when any past deviation must be corrected in the present period. The result of the granger causality test showed that there is a bi-directional relationship between export and economic growth, bi-directional relationship between import and economic growth, independent causality between exchange rate and economic growth and a bi-directional relationship between trade openness and economic growth Based on the findings it was recommended among others that government should encourage the importation of essential capital goods and discourage the excessive importation of consumable that their substitutes can be produced locally. Government should also encourage export diversification as non-oil exports should be encouraged while excessive dependence on oil exports should be discourage
\end{abstract}

Keywords: International trade, Import, Export, Economic growth.

DOI: $10.7176 / \mathrm{EJBM} / 11-34-06$

Publication date: December $31^{\text {st }} 2019$

\subsection{Introduction}

International trade is the trade that goes on between one country and other countries. Okafor and Obasi (2011) see international trade as the trade between nations in goods and services while Paul (2004) defined international trade as the exchange of goods and services between different countries or trade across the political boundaries. Dimoji, Atorudibo and Onwuneme (2013) opined that there are two types of international trade. They are bilateral international trade which is a trade that occurs when two countries agree to exchange goods and services and multilateral trade which is a type of international trade in which a country trades with many other countries According to Dewett, Navalur and Khuntia (2012) the fundamental basis of international trade lies in the fact that factor endowments are unevenly distributed among the countries of the world. This is due to geographic facts, physical features and climatic differences. Ahuja (2013) classified gains into two types: static gains and dynamic gains. Static gains from trade refer to the increase in utility or welfare of the people of trading countries as a result of the optimum utilization of their given factor- endowments for they specialize on the basis of their comparative costs. On the other hand, dynamic gains refer to the contribution which foreign trade makes to the overall growth of trading countries.

\subsection{Statement of problem}

In Nigeria, available statistics shows that Nigeria's total export and total import increased from N3087.9 billion and N2080.2 billion in 2003 to N10387.7 billion and N5593.2 billion in 2008 respectively. At the same time trade openness measured as the ratio of exports and imports to GDP rose from 16.3 percent in 2003 to 34.7 in 2008 . Moreover, in 2010, total exports and total imports in Nigeria also witness further increase from N12011.5 billion and N19280 billion respectively to N13445. Billion in2018 while trade openness increased from 36.9 percent in 2010 to 46.9 percent in 2018 (CBN statistical bulletin 2018). Given that one of the major objectives of encouraging international trade is to stimulate economic growth, the increase the level of imports, exports and trade openness is expected to generate a corresponding increase in economic growth in Nigeria. Unfortunately, increases in Nigeria's imports, exports and trade openness have not been able to generate a meaningful growth as Nigeria's economy is still experiencing some elements of instability. The study therefore seeks to investigate the impact of international trade on economic growth in Nigeria.

\subsection{Objectives of the study}

The broad objective of the study was to investigate the impact of international trade on the economic growth of 
Nigeria. The specific objectives of the study were:

(i) To investigate the impact of export economic growth in Nigeria

(ii) To examine the impact of import volume on economic growth in Nigeria

(iii) To investigate the impact of exchange rate on economic growth in Nigeria

(iv) To examine the impact trade openness on economic growth in Nigeria

\subsection{Hypothesis of the study:}

In order to guide the study, the following null hypotheses were formulated:

$\mathrm{HO}_{1}$ : Export does not have any impact on economic growth in Nigeria.

$\mathrm{HO}_{2}$ : Import does not have any impact on economic growth in Nigeria.

$\mathrm{HO}_{3}$ : Exchange rate does not have any impact on economic growth in Nigeria

$\mathrm{HO}_{4}$ : Trade openness does not have any impact on economic growth in Nigeria

\subsection{LITERATURE REVIEW}

\subsection{Theoretical literature}

2.1.1 Comparative Cost theory: The classical theory of international trade is the comparative cost theory which states that a country, in the long run, will tend to specialize in the production of and to export that commodity whose production it experience comparative cost advantage and import that commodity in whose production it experiences comparative cost disadvantage. Specialization and trade, according to the comparative cost principle, will not only make the trading countries better off but also maximize the world production through international division of labour. The assumptions of the theory include the following:

(i) Labour is the only factor of production and the value of a commodity is proportional to the quantity of labour required in its production.

(ii) All labour units are homogeneous, that is, all the labourers are equally efficient

(iii) Since there is a single factor of production, commodities are produced at constant costs.

(iv) Under the constant cost conditions, prices are determined by supply and the changes in demand have no effect on them.

(v) Factors of production are perfectly mobile within the country but completely immobile among countries.

(vi) There is free trade and government does not interfere in trade

(vii) There are no transport costs.

(viii) There is perfect competition in both commodity and factor market

(ix) The theory is based on two countries - two commodities model

(x) The two countries have common monetary standard and the quantity theory of money is considered valid. (Paul, 2004)

2.1.2 Mill's Theory of Reciprocal Demand: Ricardo expounded the theory of comparative advantage without explain the ratios at which commodities would exchange for another. It was J.S Mill who discussed the latter problem in detail in terms of his theory of reciprocal demand. Reciprocal demand' was introduced by Mill to explain the determination of the equilibrium terms of trade. It is used to indicate a country's demand for one commodity in terms of the quantities it is prepared to give up in exchange. It is reciprocal demand that determines the terms of trade which, in turn, determines the relative share of each country Equilibrium would be established at that ratio of exchange between the two commodities at which quantities demanded by each country of the commodity which it imports from the other, should be exactly sufficient to pay for one another. The theory was based on the following assumptions:

(i) There are two countries $\backslash$

(ii) There are two commodities

(iii) Both the commodities are produced under the law of constant returns

(iv) There are no transport costs

(v) The needs of the two countries are similar

(vi) There is perfect competition

(vii) There is full employment

(viii) There is free trade between the two countries

(ix) The principle of comparative costs is applicable in trade relations between the two countries (Jhinghan, 2006).

2.1.3 Heckscher-Ohlin Theory: The theory states that the main determinant of the pattern of production, specialization and trade among regions is the relative availability of factor endowment and factor prices. Regions or countries have different factor endowments and factor prices. Some countries have much capital, others have much labour. The theory says that countries that are rich in capital will export capital- intensive goods and countries that have much labour will export labour intensive goods. To Ohlin, the immediate cause of international trade always is that some commodities can be bought more cheaply from other regions, whereas in the same region their 
production is possible at high prices. Thus the main cause of trade between regions is the difference in prices of commodities based on relative factor endowments and factor prices. The theory is based on the following assumptions:

(a) It is a two-by-two-by-two model. That is there are two countries, two commodities and two factors of production.

(b) There is perfect competition in commodity as well as factor markets.

(c) There is full employment of resources

(d) There are quantitative differences in factor endowments in different regions but qualitatively they are homogeneous.

(e) The production function of the two commodities have different factor intensities, that is, labour-intensive and capital-intensive

(f) The production functions are different for different commodities, but are the same for each commodity in both countries.

(g) Factor intensities are non- reversible.

(h) There is perfect mobility of factors within each region but internationally, they are immobile.

(i) There are no transport costs.

(j) There is free trade and unrestricted trade between the two countries

(k) There are constant returns to scale in the production of each commodity in each region.

(l) Taste and preferences of consumers and their demand patterns are identical in both countries.

(m) There is no change in technological knowledge.

(n) There is incomplete specialisation. Neither country specialises in the production of one commodity (Jhingan, 2006).

\subsection{Conceptual literature}

International trade otherwise known as foreign trade or external trade entails the exchange of goods and services between two or more countries. The area of each country's specialization is the principle factor that underlines the exchange of goods and services between the countries involved (Dimoji, Atorudibo and Onwuneme 2013). According to Okafor and Obasi (2011), international trade is trade between nations in goods and services. In the words of Azeez, Dada Aluko (2014), international trade can be interchangeably referred to as 'foreign trade' or 'global trade'. It encompasses the inflow (import) and outflow (export) of goods and services in a country. Paul (2004) defined international trade as the exchange of goods and services between different countries or trade across the political boundaries.

International trade is divided into three. They are import trade, export trade and entreport trade. Import trade is the act of buying goods and services from another country. This type of trade is sometimes restricted in order to control the balance of payments. Import trade is further divided into two: they are visible and invisible imports. Visible imports involves the importation of goods that can be touched or seen while invisible imports are imports that consists of services rendered by other countries that cannot be touched. They are intangible goods. Export trade is the act of selling goods to other countries. Export subsidies are given by the government of countries as a way of encouraging export. This is because it is more favourable to export. Export is divided into visible and invisible exports. Visible exports consist of goods which are sold to other countries while invisible exports consist of services rendered to other countries. Entreport trade is the re-exporting of goods imported from other countries (Dimoji, Atorudibo and Onwuneme 2013).

International trade takes place because of the following reasons:

(i) Hunan wants are varied and unlimited and no single country possesses the resources to satisfy all these wants. Hence there arise a need for interdependence between countries in the form of international trade

(ii) International trade is the result of territorial division of labour and specialization in the countries

(iii) Factor endowments vary in different countries

(iv) Labour and entrepreneurial skills vary in different countries

(v) Factors of production are highly immobile between the countries (Paul, 2004).

The fundamental basis of international trade lies in the fact that countries are endowed by nature with different elements of productive power. In other words, factor endowments are unevenly distributed among the countries of the world. This is due to geographic facts, physical features and climatic differences. Thus, international trade is inevitable when there are marked differences in the countries, regarding materials, natural vegetation, climate, soils and other physical and geographical conditions. International trade is also affected by several other factors besides the natural or geographical factors, e.g., stage of economic development, accumulation of capital by a nation and its foreign investments, technological progress, trade and financial regulation, political affiliations and so on (Dewett, Navalur and Khuntia, 2012). Okafor and Obasi (2011) see the reason why international trade takes place as non availlability of goods and services in countries and cost differences between nations while Samuelson 
and Nordhaus (2010) see diversity in natural resources, differences in tastes and differences in costs as the reasons for international trade in goods and services.

There are basically two types of international trade. They are bilateral international trade and multilateral international trade. Bilateral international trade occurs when two countries agree to exchange goods and services. This is due to the fact that these two countries agree to balance their payments and receipts separately and individually with each other while multilateral international trade is a type of international trade in which a country trades with many other countries. The multilateral trade brings about division of labour resulting in exchange of goods and services. Multilateral international trade helps in raising the volume of the world trade to its maximum (Dimoji, Atorudibo and Onwuneme 2013).

International trade has some gains. Some of these gains include:

(i) It encourages territorial division of labour or international specialization because economies of scale are realized from expanded markets.

(ii) International specialization and economies in production lead to increase in productivity, low costs and cheaper prices.

(iii) International trade increases real income and consumption. This leads to expansion of employment and output and promote economic growth.

(iv) Trade enables a country to conserve certain scarce resources because the commodities which embody these resources can be imported from countries where they are abundant.

(v) Trade increases competition and efficiency in the trading countries.

(vi) Trade leads to optimum allocation of resources

(vii) Trade makes possible the consumption of a variety of goods and thus improves the welfare of the people of the trading countries

(viii) International trade makes available even those goods which cannot be domestically produced. (Paul, 2004).

The classical and neo-classical economists attached so much importance to international trade in a country's development that they regarded it as the engine of growth. When a country specializes in the production of a few goods due to international trade and division labour, it export those commodities which it produces cheaper in exchange for what others can produce at a lower cost. It gains from trade and there is increase in national income which, in turn, raises the level of output and growth rate of economy. This is called the direct benefit of international trade. Besides there are indirect dynamic benefits of a higher order from foreign trade and they include:

(i) Foreign trade helps to exchange domestic goods having low growth potential for foreign goods with high growth potential

(ii) Foreign trade possesses an educative effect. Under-developed countries lack in critical skills which are a greater hindrance to development that is the scarcity of capital goods.

(iii) Foreign trade provides the basis for importation of foreign capital in less developed countries. If there were no foreign trade, foreign capital would not flow from the rich to the poor countries

(iv) Foreign trade helps in checking inefficient monopolies. (Jhinghan, 2006).

According to Ahuja (3013) foreign trade confers a good deal of benefits on the trading countries. If different countries specialize on the basis of their comparative costs, it will enable them to make optimum use of their resources and thereby add to their output, income and welfare of their people. Gains from trade are broadly divided into two types: static gains and dynamic gains. Static gains from trade refer to the increase in utility or welfare of the people of trading countries as a result of the optimum utilization of their given factor- endowments for they specialize on the basis of their comparative costs. On the other hand, dynamic gains refer to the contribution which foreign trade makes to the overall growth of trading countries.

For Jhinghan (2010), there are several factors which determine the gain from international trade. They include

(i) Differences in cost ratios: The gain from international trade depends on difference in comparative cost ratios in the two trading countries. A country gains by foreign trade if and when the traders find that their exists abroad a ratio of prices from different from that to which they are accustomed at home. They buy what to them seems cheap and sell what to them seems dear.

(ii) Reciprocal demand: the terms of trade in turn depends upon reciprocal demand, that is, the relative strength and elasticity of demand of one country for the product of the other in exchange for its product.

(iii) Level of income: The level of money income of a country is another factor which determines the gain and the share of trade. A country whose goods have a constant demand in other countries will have a high level of income. If the demand for its exports is high, its export industries will expand. Consequently the level of money wages will rise in these industries. Competition for labour will force other industries to raise money wages to the level of export industries. Thus the overall level of money incomes will tend to be high in the country. So people of the country will gain as 
consumers of cheap imported goods. On the contrary, a country having high demand for foreign goods will have low money incomes. As it will have high demand for foreign goods their prices will be high. Consequently, its people will lose as consumers of those imported goods.

Ahuja (2013) sees terms of trade as the rate at which one country exchanges its goods for the goods of other countries while Ruffin and Gregory (1983) defined terms of trade as the rate at which two products can be exchanged for each other between countries. Paul, 2004 is of the opinion that the concept of terms of trade refers to the rate at which a country exchanges exports for imports. It expresses a comparison of two values: the export prices and the import prices. In other words, the concept of terms of trade is defined as the ratio of export prices to import prices. If the prices of imports rise more than the prices of exports, then the terms of trade become unfavourablle to, or move against the country in question because to obtain the same volume of imports, greater volume of exports are to be sold abroad. Similarly, if the prices of exports rise more than the prices of imports, the terms of trade become favourable to the country. Lipsey (2007) defined terms of trade are defined as the quantity of domestic goods that must be given up to get a unit of imported goods. Thus, the terms of trade are nothing more than the opportunity cost of obtaining goods through international trade rather than producing them directly.

The concepts of terms of trade include: net barter terms of trade which refers to the relation between prices of exports and prices of exports; gross barter terms of trade which refers to the relation of the volume of imports to the volume of exports and income terms of trade which refers to the index of the value of exports divided by the price of import (Ahuja 2013).

Exchange rate is the price of one currency in terms of another. It is the rate at which one currency is exchanged for another. We have real exchange rate and nominal exchange rate. Real exchange rate is the rate at which the person can trade the goods and services of one country for the goods and services of another while nominal rate is the rate at which a person can trade the currency of one country for the currency of another. We also have flexible exchange rate and fixed exchange rate.. Under the flexible exchange rate system, the rate is determined by the market forces and the rate fluctuates freely in response to changes in market conditions and there is no government intervention in the foreign exchange market while in fixed exchange rate, the government chooses a particular exchange rate and offers to buy and sell at that price. Under exchange control system, the rate of exchange is fixed by the central bank of a country. Flexibility of rate, if any is allowed within certain limits.

\subsection{Empirical literature}

Gwaison, Zakari and Maimako (2018) empirically examined the impact of international trade on economic growth in Nigeria from 1986 - 2016. The secondary data used for the study were the foreign reserve (FRESV) collected from World bank data, the oil export (OEXP) and non-oil export (NOEXP) collected from Nigerian bureau of Statistics (NBS), the gross domestic growth (GDP) and foreign direct investment (FDI) collected from Central Bank of Nigeria (CBN) Statistical Bulletin respectively. The Error correction model (ECM) technique was employed to estimate the impact of international trade on economic growth. The result of the analysis showed that international trade had a significant impact on economic growth in Nigeria from 1986-2016 at 5\% level of significance and there is a unidirectional causality among variables. The study recommended that government should provide conducive economic atmosphere that will encourage foreign investors and the government should take urgent steps to sufficiently boost the non-oil of Nigeria so that it will impact more tremendously on economic growth in the country.

Muhammad and Benedict (2015) examined the impact of international trade on economic growth in Nigeria for the period 1981 to 2012. Using degree of openness to proxy international trade, the ordinary least squares technique was employed to estimate the impact of international trade on Gross Domestic Product. The broad objective of the study was to analyze the impact of international trade on economic growth in Nigeria based on time series data on variables considered relevant indicators of economic growth and international trade. The analysis was based on data extracted from World Bank data and Central Bank of Nigeria Statistical Bulletin. The result of the analysis showed that all the variables except interest rate were statistically significant. The study recommended that policy makers should adopt policies on trade liberalization such as reduction of non-tariff barriers, reducing tariffs, reducing or eliminating quotas that will enable the economy to grow at spectacular rates. And thus this study supports the proposition that degree of openness has direct robust relationship with economic growth since the proxy variable is positive and statistically significant in the mode

Adeleye. Adeteye and Adewuyi (2015) examined the impact of international trade on economic growth in Nigeria, using net export (i.e total export less total import) and Balance of Payments as proxies for international trade while Gross Domestic Product represent economic growth. The study employed regression analysis as the method of analysis using co-integration and error correction modeling techniques to find the long-run relationship between economic performance and international trade. Only Total Export (TEX) remains positive and significant while others remain insignificant, which means, Nigeria is running a mono cultural economy where only oil act as the sole support of the economy without tangible support from other sectors such as industrial/manufacturing and 
agriculture. The study recommended that government should pursue aggressive diversification of the economy by putting in place policies and incentives that will boost non-oil export, the manufacturing sector and overall promote the industrial growth of Nigeria.

Andabai and MaryAnn (2018) investigated the relationship between international trade and performance of the Nigerian economy; for the period (1990-2017). Secondary data were used and collected from the Central Bank of Nigeria Statistical Bulletin. The study used Gross Domestic Product (GDP) and was employed as the dependent variable to measure the performance of the Nigerian economy; whereas, Import Trade, Export Trade and Trade Openness were also employed as the independent variables to measure international trade. Time series econometrics techniques were used to test the formulated hypotheses. The result revealed that the variables do not have unit roots. There is also a long-run equilibrium relationship between international trade and performance of the Nigerian economy. The result confirmed that about $68 \%$ short-run adjustment speed from long-run disequilibrium. The study revealed that there is a causal relationship between international trade and performance of the Nigerian economy. The coefficient of determination indicated that about $62 \%$ of the variations of performance of Nigerian economy can be explained by changes in international trade variables. The study concluded that international trade had a causal relationship with performance of the Nigerian economy. The study recommended that government policies should be directed towards lifting trade barriers from local output. Government should embrace economic diversification in order to address the issue of monoculture export syndrome. Government should ensure political and economic stability so as to encourage investment, both local and foreign and guarantee business survival. Non-oil sector exports should be encouraged that will add value to the growth and development of the Nigerian economy

Imoughele, and Ismaila (2016) examined the impact of international trade on Nigeria economic growth. The study employed empirical analysis in examining the effect of international trade variables (openness of the economy, volume of import, export, foreign direct investment and exchange rate) on Nigeria economic growth using time series data from 1985 to 2013. The Augmented Dickey-Fuller (ADF) test was used for the unit root test and Johansen's co-integration test was also conducted to establish short and long run relationships between economic growth and foreign trade variables. The result of the study showed two co-integrating equations which established the existence of long run relationship among the variables. The ordinary Least Square statistical technique was used to assess the degree of influence the variables have on each other. The results showed that export, foreign direct investment and openness of the economy has direct and significant impact on Nigeria economic growth also exchange rate has direct but insignificant impact on the nation economy while volume of import has inverse and insignificant impact on the Nigerian economy. From the findings, the study concluded that foreign trade variables of export, foreign direct investment and openness of the economy have the tendency to improve and sustained the nation economic performance and stabilised the country trade with other nations of the world. The study recommended among others that government should ensure that adequate macroeconomic policies that will open up the economy are put in place to encourage foreign direct investment inflow and expand Nigeria exportation of goods and services for the established international market in view of the fact that exports are driver of economic growth

Azeez, Dada and Aluko (2014) examined the effect of international trade on the economic growth of Nigeria in the 21 st century. The model specified economic growth measured by gross domestic product as dependent on international trade proxy by imports, exports, and trade openness. Annual time series data from 2000-2012 was sourced and analysed using Ordinary Least Square (OLS) estimation technique. It was evidenced that international trade has a significant positive impact on economic growth. Imports, Exports, and Trade Openness have significant effect on the economy. The study recommended that government should reduce over-dependence on oil exports and increase and diversify its export base to earn more revenue

Elias, Agu and Eze (2018) evaluated the impact of international trade on the Nigeria economic growth. The objectives of the study were to ascertain the impact of export trade on the Nigerian economy and to determine the impact of import trade on the Nigerian economy. Multiple regression analysis technique was employed in estimating the various components of foreign trade. The data used for the study was extracted from the 2012 edition of the CBN statistical bulletin, covering the period from $1980-2012$. The results of the study showed that there is a significant impact of export trade on the Nigerian economic growth. The study also revealed that there is no significant impact of import trade on the Nigerian economic growth. The study recommended among other things that conscious efforts should be made by government to fine-tune the various macroeconomic variables in order to provide an enabling environment to stimulate foreign trade by engaging in more of export trade and in effect curtail on import trade which has a negative effect or strain the economy, the underground economic activities of bunkering, smuggling, child and drug trafficking, and other related illegal activities should he properly checked, it was also recommended that the government should encourage export diversification, e.g. non-oil sector exports should be encouraged and concentration on oil sector export should be minimized. 


\subsection{Methodology}

Multiple regression analysis was used in the study. Time series data spanning from 1981 to 2018 was sourced from the Central Bank of Nigeria statistical bulletin and. Securities and Exchange Commission, statistical bulletin. The data were analysed using E-views. 10

\subsection{Model specification}

In order to investigate the impact of international trade on the economic growth of Nigeria, the model for this study was specified thus;

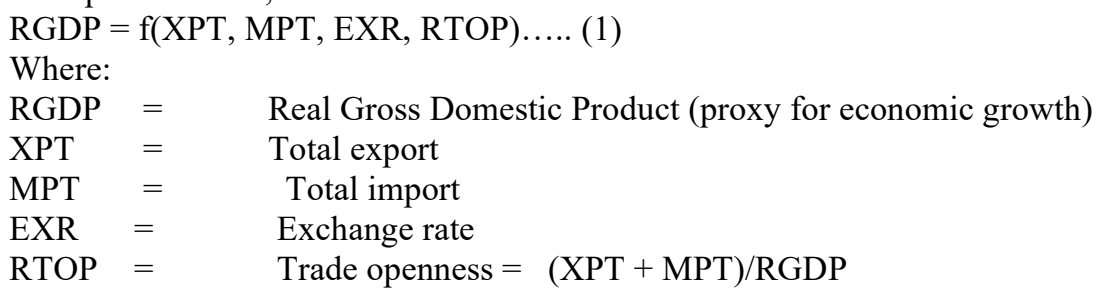

Where:

$\mathrm{RGDP}=\quad$ Real Gross Domestic Product (proxy for economic growth)

$\mathrm{XPT}=$ Total export

MPT $=$ Total import

$\mathrm{EXR}=$ Exchange rate

$\mathrm{RTOP}=\quad$ Trade openness $=(\mathrm{XPT}+\mathrm{MPT}) / \mathrm{RGDP}$

The model in its econometric linear form can be written as:

$\begin{array}{llc}\mathrm{RGDP} & = & \mathrm{b}_{0}+\mathrm{b}_{1} \mathrm{XPT}+\mathrm{b}_{2} \mathrm{MPT}+\mathrm{b}_{3} \mathrm{EXR}+\mathrm{b}_{4} \mathrm{RTOP}+\mathrm{U} \\ \mathrm{U} & = & \text { stochastic or random error term } \\ \mathrm{b}_{\mathrm{o}} & = & \text { constant intercept } \\ \mathrm{b}_{1}-\mathrm{b}_{4}= & \text { coefficients of associated variables }\end{array}$

The model in the log linear form can be expressed as:

$\operatorname{LogGDP}=b_{0}+b_{1} \operatorname{LogXPT}+b_{2} \log M P T+b_{3} \operatorname{LogEXR}+b_{4} \operatorname{LogRTOP}+\mathrm{U}----(3)$

Where:

$\log =$ natural logarithm

The theoretical expectations about the signs of the coefficients of the parameters are as follow: $b_{1}>0, b_{2}<0$, b3 $>0$, b4 $>0$.

Since the data for the analysis is time series, the Augmented Dickey-Fuller (ADF) unit root test was employed to ensure data stationarity and avoid the problem of spurious regression. The Johansen test for co-integration was also employed to investigate whether there is existence of long run relationship among the variables in the model. Vector error correction model was also adopted to determine the rate of adjustment from short run equilibrium to long run equilibrium.

Table 1.1: Result of Augmented Dickey-Fuller unit root test result

\begin{tabular}{|l|l|l|l|}
\hline Variables & ADF test statistic & $5 \%$ critical value & Order of integration \\
\hline RGDP & -4.844472 & -2.943427 & $1(0)$ \\
\hline XPT & -3.138823 & -2.945842 & $1(1)$ \\
\hline MPT & -6.040090 & -3.544285 & $1(1)$ \\
\hline EXR & -4.538985 & -3.540328 & $1(1)$ \\
\hline RTOP & -4.234972 & -3.540328 & $1(1)$ \\
\hline
\end{tabular}

Table 1.2: Result of Phillips-Perron unit root test result

\begin{tabular}{|l|l|l|l|}
\hline Variables & PP test statistic & $5 \%$ critical value & Order of integration \\
\hline RGDP & -4.854993 & -2.943427 & $1(0)$ \\
\hline XPT & -2.968079 & -1.950394 & $1(1)$ \\
\hline MPT & -4.621784 & -2.945842 & $1(1)$ \\
\hline EXR & -4.538085 & -3.540328 & $1(1)$ \\
\hline RTOP & -4.837362 & -3.540328 & $1(1)$ \\
\hline
\end{tabular}

The Augmented Dickey-Fuller unit root test result presented on table 1.1 and the Phillips-Perron unit root test result presented on table 1.2 showed that RGDP was stationary at levels while other variables (XPT, MPT, EXR and RTOP) were stationary at first difference. This is because their various ADF test statistic and PP test statistic were greater than their various $5 \%$ critical values in absolute terms. 
Table 2: Johanssen co-integration test result

Sample (adjusted): 19832018

Included observations: 36 after adjustments

Trend assumption: Linear deterministic trend

Series: RGDP XPT MPT EXR RTOP

Lags interval (in first differences): 1 to 1

Unrestricted Cointegration Rank Test (Trace)

\begin{tabular}{|c|c|c|c|c|}
\hline $\begin{array}{l}\text { Hypothesized } \\
\text { No. of CE(s) }\end{array}$ & Eigenvalue & $\begin{array}{c}\text { Trace } \\
\text { Statistic }\end{array}$ & $\begin{array}{c}0.05 \\
\text { Critical Value }\end{array}$ & Prob.** \\
\hline None * & 0.678468 & 88.66733 & 69.81889 & 0.0008 \\
\hline At most 1 & 0.535618 & 47.81969 & 47.85613 & 0.0504 \\
\hline At most 2 & 0.299246 & 20.20595 & 29.79707 & 0.4090 \\
\hline At most 3 & 0.171017 & 7.404414 & 15.49471 & 0.5311 \\
\hline At most 4 & 0.017960 & 0.652429 & 3.841466 & 0.4192 \\
\hline
\end{tabular}

Trace test indicates 1 cointegrating eqn(s) at the 0.05 level

* denotes rejection of the hypothesis at the 0.05 level

**MacKinnon-Haug-Michelis (1999) p-values

Unrestricted Cointegration Rank Test (Maximum Eigenvalue)

\begin{tabular}{ccccc}
\hline \hline $\begin{array}{c}\text { Hypothesized } \\
\text { No. of CE(s) }\end{array}$ & Eigenvalue & $\begin{array}{c}\text { Max-Eigen } \\
\text { Statistic }\end{array}$ & $\begin{array}{c}0.05 \\
\text { Critical Value }\end{array}$ & Prob. ${ }^{* *}$ \\
\hline \hline None ${ }^{*}$ & 0.678468 & 40.84764 & 33.87687 & 0.0063 \\
At most 1 & 0.535618 & 27.61374 & 27.58434 & 0.0496 \\
At most 2 & 0.299246 & 12.80154 & 21.13162 & 0.4707 \\
At most 3 & 0.171017 & 6.751985 & 14.26460 & 0.5189 \\
At most 4 & 0.017960 & 0.652429 & 3.841466 & 0.4192 \\
\hline \hline
\end{tabular}

Max-eigenvalue test indicates 2 cointegrating eqn(s) at the 0.05 level

* denotes rejection of the hypothesis at the 0.05 level

**MacKinnon-Haug-Michelis (1999) p-values

The trace test indicates that there was 1 co-integrating equation at 0.05 level while the max-eigen value test indicates that there were 2 co-integrating equations at 0.05 level. These results showed that the variables are cointegrated. That is, RGDP has a long run relationship with XPT, MPT, EXR and RTOP

The ordinary least square (OLS) result conducted on the specified model is presented on table 3 . The OLS result reveals the short run relationship that exists between the dependent variable and each of the explanatory variables. 
Table 3. Ordinary Least Square (OLS) Results: Short-Run Analysis

Dependent Variable: LOG(RGDP)

Method: Least Squares

Sample: 19812018

Included observations: 38

\begin{tabular}{|c|c|c|c|c|}
\hline Variable & Coefficient & Std. Error & t-Statistic & Prob. \\
\hline $\mathrm{C}$ & 0.713381 & 0.053449 & 13.34685 & 0.0000 \\
\hline LOG(XPT) & 0.582154 & 0.009404 & 61.90708 & 0.0000 \\
\hline LOG(MPT) & 0.414046 & 0.008311 & 49.81806 & 0.0000 \\
\hline LOG(EXR) & 0.003217 & 0.001970 & 1.633341 & 0.1119 \\
\hline LOG(RTOP) & -0.996651 & 0.006144 & -162.2098 & 0.0000 \\
\hline R-squared & 0.999504 & Mean dependent var & & 10.32956 \\
\hline Adjusted R-squared & 0.999443 & S.D. dependent var & & 0.639486 \\
\hline S.E. of regression & 0.015086 & Akaike info criterion & & -5.427990 \\
\hline Sum squared resid & 0.007511 & Schwarz criterion & & -5.212518 \\
\hline Log likelihood & 108.1318 & Hannan-Quinn criter. & & -5.351327 \\
\hline F-statistic & 16612.21 & Durbin-Watson stat & & 1.320922 \\
\hline Prob(F-statistic) & 0.000000 & & & \\
\hline
\end{tabular}

From the results of the OLS, the constant parameter (Bo) is positive at 0.713381 . This means that if all the independent variables are held constant, RGDP as a dependent variable will on the average increase by 71.3 percent. For XPT, the coefficient is 0.582154 . This means that XPT is positively related to RGDP implying that on the average, one percent increase in XPT will lead to 58.22 percent increase in RGDP and this is in conformity to the aprori expectation. The t-value of export (XPT) is 61.90708 with the probability value of $0.000<0.05$ (level of significance) shows that export (XPT) has a significant effect on real gross domestic product (RGDP) in Nigeria within the period under study. The result also showed that the coefficient of MPT is 0.414046 implying that there is a positive relationship between MPT and RGDP and this is contrary to the aprori expectation. The result showed that on the average, one percent increase in MPT will lead to 41.4 percent increase in RGDP. The t-value of import (MPT) is 49.81806 with the probability value of $0.000<0.05$ (level of significance) shows that import (MPT) has a significant effect on real gross domestic product (RGDP) in Nigeria within the period under study. The result equally showed that the coefficient of EXR is 0.003217 meaning that there is a positive relationship between EXR and RGDP and this is also in conformity to the aprori expectation. From the result, one percent increase in EXR will on the average lead to 0.3 percent increase in RGDP. The t-value of exchange rate (EXR) is 1,633341 with the probability value of $0.1119>0.05$ (level of significance) shows that exchange rate (EXR) does not have a significant effect on real gross domestic product (RGDP) in Nigeria within the period under study. The result also revealed that the coefficient of RTOP is -0.996651 implying that RTOP has a negative relationship with RGDP and is not conformity with the aprori expectation. The result showed that on the average, one percent increase in RTOP will lead to 99.7 percent fall in RGDP. The t-value of trade openness (RTOP) is -162.2098 with the probability value of $0.000<0.05$ (level of significance) shows that trade openness (RTOP) has a significant effect on real gross domestic product (RGDP) in Nigeria within the period under study. The R-squared value of as 0.999504 showed that about $99.9 \%$ of the total variations in the dependent variable (RGDP) were explained by changes in the explanatory variables (XPT, MPT, EXR and RTOP). The F-statistic of 16612.21 with the corresponding probability value of 0.0000 measured the adequacy of the regression model and the overall influence of XPT, MPT, EXR and RTOP on RGDP. Since P $=0.000<0.05$ (level of significance), the model was a good fit and the explanatory variables (XPT, MPT, EXR and RTOP) jointly exerted a statistically significant effect on the dependent variable (RGDP). The Durbin-Watson value of 1.32092 shows the presence positive of autocorrelation.

The next step is to perform the over parameterised and parsimonious error correction method to account for short- run dynamic adjustments required for stable long run relationship among the variables in the model. The over parameterized model is presented in table 4. The over parameterized model account for model misspecification problems as a step towards arriving at a preferred or parsimonious model. This is presented below. 
Table 4 Over-Parameterised Error Correction Results.

Dependent Variable: DLOG(RGDP)

Method: Least Squares

Sample (adjusted): 19842018

Included observations: 35 after adjustments

\begin{tabular}{crrrr}
\hline \hline Variable & Coefficient & Std. Error & t-Statistic & Prob. \\
\hline C & -0.006363 & 0.004271 & -1.489802 & 0.1511 \\
DLOG(XPT) & 0.588389 & 0.014335 & 41.04699 & 0.0000 \\
DLOG(XPT(-1)) & 0.009688 & 0.013048 & 0.742452 & 0.4660 \\
DLOG(XPT(-2)) & 0.017457 & 0.013468 & 1.296150 & 0.2090 \\
DLOG(MPT) & 0.409903 & 0.017407 & 23.54768 & 0.0000 \\
DLOG(MPT(-1)) & 0.009730 & 0.016501 & 0.589685 & 0.5617 \\
DLOG(MPT(-2)) & 0.010871 & 0.019615 & 0.554236 & 0.5853 \\
DLOG(EXR) & -0.001833 & 0.010343 & -0.177260 & 0.8610 \\
DLOG(EXR(-1)) & 0.008292 & 0.009670 & 0.857493 & 0.4009 \\
DLOG(EXR(-2)) & 0.004474 & 0.004758 & 0.940259 & 0.3578 \\
DLOG(RTOP) & -1.001204 & 0.006678 & -149.9320 & 0.0000 \\
DLOG(RTOP(-1)) & -0.006646 & 0.010798 & -0.615554 & 0.5448 \\
DLOG(RTOP(-2)) & -0.020454 & 0.016037 & -1.275421 & 0.2161 \\
ECM(-1) & -0.658434 & 0.207921 & -3.166758 & 0.0046 \\
R-squared & 0.999578 & Mean dependent var & & 0.046215 \\
Adjusted R-squared & 0.999317 & S.D. dependent var & & 0.557953 \\
S.E. of regression & 0.014586 & Akaike info criterion & & -5.328366 \\
Sum squared resid & 0.004468 & Schwarz criterion & -4.706226 \\
Log likelihood & 107.2464 & Hannan-Quinn criter. & & -5.113603 \\
F-statistic & 3825.496 & Durbin-Watson stat & & 1.639917 \\
Prob(F-statistic) & 0.000000 & & \\
\hline \hline
\end{tabular}

In the over parameterized model as shown in table 4, the error correction term ECM (-1) is correctly specified. It is negative and statistically significant. This means that it will be effective to correct any deviations from the long-run equilibrium. Moreover, the negative and statistically

significant of the ECM confirms that the variables in the model are co- integrated The coefficient of the $\operatorname{ECM}(-1)$ which is -0.658434 indicates that the speed of adjustment to long run equilibrium is 65.8 percent when any past deviation must be corrected in the present period. This means that the present value of RGDP adjusts so fast to changes in XPT, MPT, EXR and RTOP. The coefficient of determination $\left(\mathrm{R}^{2}\right)$ in the over parameterized model is 0.999578 . This means that about 99.9 percent of the variations in the dependent variable (RGDP) is explained jointly by the explanatory variables in the model. The F-statistic of 3525.496 with probability of 0.0000 is significant. This means that the explanatory variables in the model (XPT, MPT, EXR and RTOP) are jointly significant. The Durbin Watson statistic of 1.639917 means the absence of autocorrelation. XPT in the current period is positive and statistically significant on the current RGDP and is also in conformity with the aprori expectation while XPT in the one lag period and in the two lag periods are positive and also in conformity with the aprori expectation .T they are also statistically insignificant on the current RGDP. MPT in the current period is positive and statistically significant on the current RGDP and is not in conformity with the aprori expectation. MPT in the one lag period and in the two lag periods are positive and also not in conformity with the aprori expectation. They are also statistically insignificant on the current RGDP. EXR in the current period is negative and statistically insignificant on the current RGDP and is also not in conformity with the aprori expectation while EXR in the one lag period and in the two lag periods are positive and also in conformity with the aprori expectation .T they are also statistically insignificant on the current RGDP. RTOP in the current period is negative and statistically significant on the current RGDP and is also not in conformity with the aprori expectation while RTOP in the one lag period and in the two lag periods are negative and also not in conformity with the aprori expectation .They are also statistically insignificant on the current RGDP.

The next step is to perform the parsimonious model which is a stepwise reduction of jointly insignificant variables in the over parameterized model until parsimony is achieved. In other word, the parsimonious model would be built by estimating the equations of only those variables found to be significant in the over-parameterized model. This is presented in table 5 
Table 5. Parsimonious Error Correction Result

Dependent Variable: DLOG(RGDP)

Method: Least Squares

Sample (adjusted): 19842018

Included observations: 35 after adjustments

\begin{tabular}{|c|c|c|c|c|}
\hline Variable & Coefficient & Std. Error & t-Statistic & Prob. \\
\hline $\mathrm{C}$ & -0.001256 & 0.003207 & -0.391647 & 0.6982 \\
\hline DLOG(XPT) & 0.591525 & 0.010567 & 55.97948 & 0.0000 \\
\hline DLOG(MPT) & 0.405584 & 0.011446 & 35.43392 & 0.0000 \\
\hline DLOG(EXR(-2)) & 0.004889 & 0.003594 & 1.360269 & 0.1842 \\
\hline DLOG(RTOP) & -0.998613 & 0.005477 & -182.3170 & 0.0000 \\
\hline ECM(-1) & -0.659383 & 0.183605 & -3.591306 & 0.0012 \\
\hline R-squared & 0.999437 & Mean dependent var & & 0.046215 \\
\hline Adjusted R-squared & 0.999340 & S.D. dependent var & & 0.557953 \\
\hline S.E. of regression & 0.014329 & Akaike info criterion & & -5.498281 \\
\hline Sum squared resid & 0.005954 & Schwarz criterion & & -5.231650 \\
\hline Log likelihood & 102.2199 & Hannan-Quinn criter. & & -5.406240 \\
\hline F-statistic & 10304.75 & Durbin-Watson stat & & 1.515646 \\
\hline Prob(F-statistic) & 0.000000 & & & \\
\hline
\end{tabular}

In the parsimonious model as shown in table 5, the error correction term ECM (-1) is correctly specified. It is negative and statistically significant. This means that it will be effective to correct any deviations from the longrun equilibrium. The speed of adjustment which is the coefficient of ECM (-1) is -0.659383 . This shows that about 65.9 percent of short run disequilibrium adjusts back to equilibrium in the long run. This indicates that present value of the dependent variable adjusts faster to changes in the independent variables than what is obtained in the over-parameterized model. The coefficient of determination $\left(\mathrm{R}^{2}\right)$ in the parsimonious model is 0.999437 . This means that about 99.9 percent of the variations in the dependent variable (RGDP) are explained jointly by the explanatory variables in the model. The F- statistic of 10304.75 with probability of 0.000030 is highly significant. The Durbin Watson statistic of 1.515646 means the absence of autocorrelation. The result of the parsimonious model showed that the coefficients of the current XPT is 0.591525 and is statistically significant. This value of the coefficient shows that on the average, one percent increase in current XPT will lead to 59.15 percent increase in the current RGDP. The result also revealed that the coefficient of MPT is 0.405584 and is statistically significant. The value of the coefficient showed that on the average, one percent increase in current MPT of will lead to 40.56 percent increase in the current RGDP. The result equally revealed that the coefficient of EXR (-2) is 0.004889 and is not statistically significant. The value of the coefficient shows that one percent increase in the two lag periods of EXR will on the average lead to 0.49 percent increase in the current RGDP. The result equally revealed that the coefficient of RTOP is -0.998613 and is statistically significant. The value of the coefficient shows that one percent increase in the current period of RTOP will on the average lead to 99.86 percent decrease in the current RGDP.

Table 6: Pairwise Granger Causality Tests result

Pairwise Granger Causality Tests

Sample: 19812018

Lags: 2

\begin{tabular}{lcrr}
\hline \hline Null Hypothesis: & Obs & F-Statistic & Prob. \\
\hline \hline LOG(XPT) does not Granger Cause LOG(RGDP) & 36 & 5.03156 & 0.0128 \\
LOG(RGDP) does not Granger Cause LOG(XPT) & & 5.17253 & 0.0115 \\
\hline \hline LOG(MPT) does not Granger Cause LOG(RGDP) & 36 & 5.00730 & 0.0130 \\
LOG(RGDP) does not Granger Cause LOG(MPT) & & 12.4803 & 0.0001 \\
\hline \hline LOG(EXR) does not Granger Cause LOG(RGDP) & 36 & 0.39909 & 0.6743 \\
LOG(RGDP) does not Granger Cause LOG(EXR) & & 55.5234 & $6 . \mathrm{E}-11$ \\
\hline \hline LOG(RTOP) does not Granger Cause LOG(RGDP) & 36 & 5.13901 & 0.0118 \\
LOG(RGDP) does not Granger Cause LOG(RTOP) & & 11.2957 & 0.0002 \\
\hline \hline
\end{tabular}

Source: Author's computation using E-views 10 
To determine the direction of causality between the variables, causality test was performed on the variables as indicated in table 6 . A causality test states that if the probability value of the estimate is higher than $5 \%(0.05)$ level of significance, we accept the null hypothesis, and vice versa. The result of the granger causality test showed that export (XPT) granger causes real gross domestic product (RGDP) while real gross domestic product also granger causes export (XPT) showing that there is a bi-directional relationship between XPT and RGDP. The result equally revealed that import (MPT) granger cause real gross domestic product (RGDP) while real gross domestic product equally granger cause import (MPT) equally showing that there is a bi-directional relationship between MPT and RGDP. The result also showed that exchange rate (EXR) does not granger cause real gross domestic product while RGDP equally does not granger cause exchange rate implying that there exists independence causality between EXR and RGDP.. The result also revealed that trade openness (RTOP) granger causes RGDP while RGDP equally granger causes RTOP equally implying that that there is a bi-directional relationship between RTOP and RGDP.

\subsection{Summary}

The study examined the impact of international trade on the economic growth of Nigeria for the period 1981-2018 The short run regression result showed that all the international trade variables (XPT, MPT and RTOP) were statistically significant except exchange rate (EXR) that was not statistically significant. The result also showed that XPT, MPT and EXR have a positive impact on the economic growth of Nigeria while RTOP has a negative impact on the economic growth of Nigeria. The result of the parsimonious model showed that XPT and MPT have a positive and significant impact on the economic growth of Nigeria. The result also showed that EXR in the two lag periods and RTOP have a negative impact on the economic growth of Nigeria. The result equally revealed that while exchange rate in the two period lags were not statistically significant, RTOP was statistically significant. The joint effect of the explanatory variables on the dependent variable was statistically significant implying that these variables were considered important variables in explaining changes in economic growth proxied by RGDP in Nigeria within the period of study. The modeled and operationalized framework of analysis exhibited a very high explanatory power, thereby providing supporting evidence that the explanatory variables included in the model were relevant in explaining changes in economic growth (RGDP) in Nigeria within the period of study The result of the granger causality test showed that there is a bi-directional relationship between XPT and RGDP, bidirectional relationship between MPT and RGDP, independent causality between EXR and RGDP and a bidirectional relationship between RTOP and RGDP

4.2 Conclusion: Given that the joint effect of the explanatory variables on the dependent variable were statistically significant, the study concludes that the international trade variables considered in this study were important variables in explaining economic growth in Nigeria within the period of study

\subsection{Recommendations}

Based on the findings, the study recommends the following:

i. Government should encourage the importation of essential capital goods and discourage the excessive importation of consumable that their substitutes can be produced locally.

ii. Government should encourage export diversification as non-oil exports should be encouraged while excessive dependence on oil exports should be discouraged.

iii. Government should adopt and implement policies that will stimulate and strengthened the manufacturing sector so as to improve on the quality of our manufacturing product so that our exports will become attractive and highly competitive in the international market. This can partly be achieved through reduction in excise duties.

iv. The monetary authorities should pursue policies that will encourage stability in the exchange rate and avoid those policies that will lead to unnecessary over valuation or depreciation of naira.

v. Government should introduce appropriate macroeconomic policies that will attract foreign direct investment in other to encourage participation in international trade.

\section{References}

Adeleye, J. O. Adeteye O. S. and Adewuyi, M. O. (2015). Impact of International Trade on Economic Growth in Nigeria (1988 - 2012). International Journal of Financial Research 6(3):163 - 172.

Ahuja, H.L (2013). Modern Economics. New Delhi: S. Chand \& Company PVT Ltd.

Andabai, P and MaryAnn, N (2018). International Trade and Performance of the Nigerian economy (1990 2017): A causality Investigation. Research Journal of Finance and Accounting 9(4): 166 - 171.

Azeez, B A; Dada, S O and Aluko, O. A (2014). Effect of International Trade on Nigerian Economic Growth: the $21^{\text {st }}$ century experience. International Journal of Economics, Commerce and Management 11(10): 1- 8.

Chang, R.; Kaltani, L. \& Loayza, N.V. (2009). Openness Can Be Good for Growth: The Role of Policy 
Complementaries. Journal of Development Economics 90 (1): 33-49.

Dewett, K.K and Navalur, M.H (2012). Modern Economic Theory. New Delhi: S. Chand \& Company PVT Ltd. Dimoji, F.A; Atorudibo, A and Onwuneme, L.N (2013). Principles of Macroeconomics: An Introductory Text. Aba: Zemek Publishers.

Edoumiekumo, S.G. \& Opukri, C.O. (2013). Economic Growth Factor in Nigeria: The Role of Global Trade. American Journal of Humanities and Social Sciences 1(2): 51-55.

Elias, I. A; Agu, R. E and Eze, L. O (2018). Impact of International Trade on the Economic Growth of Nigeria. European Journal of Business and Management 10(18): 22-30.

Emeka, E.J., Frederick, I. \& Peter, A. (2012). Macroeconomic Impact of Trade on Nigerian Growth: An Empirical Evaluation. Research Journal of Business Management and Accounting 1(4): 79-83.

Gwaison, P.D; Zakari, S and Maimako, L. N (2018). Impact of International Trade on Economic Growth in Nigeria: A Causality Approach )1986 -2016). Dutse Journal of Economics and Development Studies 6(1): 132- 143 .

Imoughele, L. E and Ismaila, M (2016) The Nexus between International trade and economic growth: The Nigerian experience. Global journal of Research in Business and Management 4(1): 246 - 253.

Jhingan, M.L (2006). International Economics. Delhi: Vrinda Publications Ltd.

Jhingan, M.L (2010). Money, Banking, International Trade and Public Finance. Delhi: Vrinda Publications Ltd. Lipsey, R.G (2007).An Introduction to Positive Economics. Great Britain: Reewood Born Limited.

Muhammad, M. Y and Benedict, N. A (2015). The Impact of International Trade in Nigeria: 1981 - 2012. European Journal of Business, Economics and Accountancy 3(6): 26 -36.

Musila, J.W. and Yiheyis, Z. (2015). The Impact of Trade Openness on Growth: The case of Kenya. Journal of Policy Model 37: 342-354.

Okafor, J.C and Obasi, A (2011). Fundamentals of Macro-economics. Enugu: Hipuks Additional Press.

Paul, R.R (2004). Money Banking and Internal Trade. New Delhi: Kalyani Publishers.

Ruffin, R.J and Gregory, P.R (1983). Principles of Economics. Illinois: Scott, Foresman and Company.

Samuelson, P.A and Nordhaus, W.D (2010). Economics. New York: McGraw-Hills Company

Ulaşan, B. (2015). Trade Openness and Economic Growth: Panel Evidence. Applied Economic Letter 22 (2): 163 167. 